\title{
Risiko Gangguan Kesehatan Masyarakat Akibat Pajanan PM10 di Kota Padang
}

\author{
Erdi Nur*, Basuki Ario Seno, Rahmi Hidayanti \\ Jurusan Kesehatan Lingkungan Poltekkes Kemenkes Padang, Jln Simpang Pondok Kopi Siteba Padang 25146, Indonesia \\ *Corresponding author: nurerdi@ymail.com
}

Info Artikel:Diterima 21 Oktober 2020 ; Disetujui 31 Maret 2021 ; Publikasi 1 Oktober 2021

Cara sitasi (Vancouver): Nur E, Seno BA, Hidayanti R. Risiko Gangguan Kesehatan Masyarakat Akibat Pajanan PM10 di Kota Padang. Jurnal Kesehatan Lingkungan Indonesia [Online]. 2021 Oct;20(2):97-103.

https://doi.org/10.14710/jkli.20.2.97-103.

\begin{abstract}
ABSTRAK
Latar belakang: Pencemaran udara merupakan salah satu permasalahan kesehatan masyarakat yang mempunyai dampak serius pada kesehatan manusia dan kualitas lingkungan. Salah satu polutan udara yang dapat menyebabkan masalah kesehatan adalah partikel debu/ Particullate Matter (PM10). Kegiatan penambangan tanah liat di Gunung Sarik merupakan yang terbesar di Kota Padang. Proses pengangkutan tanah liat ke perusahaan, menimbulkan dampak terhadap masyarakat dan lingkungan sekitarnya. Penelitian bertujuan menganalisis risiko lingkungan pajanan $\mathrm{PM}_{10}$ kegiatan penambangan tanah liat dan manajemen risiko yang dapat dilakukan.

Metode: Penelitian menggunakan metode Analisis Risiko Kesehatan Lingkungan (ARKL). Penelitian dilakukan pada bulan April sampai November 2019, sebanyak 53 responden. Parameter yang diukur adalah $\mathrm{PM}_{10}$ pada empat titik pengukuran. Teknik pengambilan sampel secara systematik random sampling. Instrumen berupa LVAS, termohygrometer, anemometer, timbangan dan kuesioner. Analisis data menggunakan tahapan analisis risiko lingkungan.

Hasil: Konsentrasi $\mathrm{PM}_{10}$ adalah $0,152 \mu \mathrm{g} / \mathrm{m}^{3}$ melebihi baku mutu sesuai dengan Peraturan Pemerintah Nomor 41 Tahun 2009. Nilai intake pajanan $\mathrm{PM}_{10}$ secara inhalasi di titik empat memiliki nilai RQ $>1$, menunjukkan bahwa pemajanan tidak aman bagi masyarakat di sepanjang jalan Gunung Sarik sehingga perlu dilakukan pengendalian.

Simpulan: Hasil penelitian menunjukkan bahwa terdapat satu titik pengukuran dengan konsentrasi $\mathrm{PM}_{10} \mathrm{udara}$ ambien di Gunung Sarik 0,152 $\mu \mathrm{g} / \mathrm{m} 3$ melewati baku mutu sesuai PP No 41 Tahun 2009 yaitu $150 \mu \mathrm{g} / \mathrm{m}^{3}$. Hasil analisis risiko $\mathrm{RQ}>1$, artinya pemajanan tidak aman bagi masyarakat yang tinggal di sepanjang Jalan Gunung Sarik dan sebanyak 43 responden (86\%) memiliki gejala gangguan saluran pernafasan
\end{abstract}

Kata kunci: Analisis risiko; Penambangan tanah liat; PM10; Pajanan

\section{ABSTRACT}

Title: Public Health Problems Due to PM10 Exposure in Padang City

Background: Air pollution is a public health problem that has a serious impact on human health and environmental quality. One of the air pollutants that can cause health problems is dust particles / Particullate Matter $\left(P M_{10}\right)$. The clay mining activity in Gunung Sarik is the largest in Padang City. The process of transporting clay to the company has an impact on the community and the surrounding environment. This study aims to analyze the environmental risk of exposure to $P M_{10}$ clay mining activities and the risk management that can be carried out.

Method: The study used the Environmental Health Risk Analysis (ARKL) method. The study was conducted from April to November 2019, with a total of 53 respondents. The measured parameter is the four point PM10 
measurement. The sampling technique is systematic random sampling. Instruments using LVAS, thermohygrometer, anemometer, scales and questionnaires. Data analysis uses the environmental risk analysis stage.

Result: The concentration of PM10 is $0.152 \mu \mathrm{g} / \mathrm{m}^{3}$ exceeding the quality standard in accordance with Government Regulation No. 41 of 2009. The value of PM10 exposure by inhalation at point four has a value of $R Q>1$, indicating that the exposure is not safe for the community along the Gunung Sarik road so it needs to be done control.

Conclusion: The results showed that there was a single point of measurement with the concentration of PM10 in ambient air at Mount Sarik $0.152 \mu \mathrm{g} / \mathrm{m} 3$ passing the quality standard according to Government Regulation No. 41 of 2009, namely $150 \mu \mathrm{g} / \mathrm{m} 3$. The results of the risk analysis $R Q>1$, meaning that the exposure is not safe for people who live along Jalan Gunung Sarik and as many as 43 respondents (86\%) have symptoms of respiratory problems.

Keywords: Risk analysis; Clay mining; $P M_{10}$; exposed

\section{PENDAHULUAN}

Pencemaran udara merupakan salah satu permasalahan kesehatan masyarakat yang mempunyai dampak serius pada kesehatan manusia dan kualitas lingkungan. Umumnya terjadi di negara berkembang dan mempunyai banyak industri, terutama dihasilkan oleh lalu lintas kendaraan, aktivitas industri dan pemanas rumah selama musim dingin. ${ }^{(1)}$ Banyak penelitian yang dilakukan di belahan dunia mebuktikan bahwa pencemaran udara mengakibatkan gangguan kesehatan pada manusia. (2) Pencemaran udara dapat terjadi di luar ruangan (outdoor) maupun di dalam ruangan (indoor). Pencemaran udara pada daerah perkotaan dan daerah industri menghasilkan berbagai macam polutan. Polutan yang biasa di temukan adalah PM10, PM 2,5, NO2, SO2, CO dan HC. ${ }^{(3)}$

Data World Health Organization (WHO) tahun 2016, pencemaran udara berasal dari asap pembakaran kendaraan bermotor, industri, sumber pembangunan, dan aktifitas di jalanan. Sebesar 98\% kota di negara berpenghasilan rendah dan menengah mempunyai kualitas udara yang tidak memenuhi standar WHO. ${ }^{(4)}$

Salah satu polutan udara yang dapat menyebabkan masalah dalam kesehatan adalah partikel debu/ Particullate Matter $\left(\mathrm{PM}_{10}\right)$, merupakan salah satu polutan udara yang memiliki tingkat toksisitas yang tinggi dan mempunyai peran dalam rusaknya udara ambient. Debu mengandung partikel zat padat dan cair yang dapat ditemukan di udara dan menimbulkan gangguan saluran pernafasan dan mencemari udara. ${ }^{(5)}$ Particullate Matter $\left(\mathrm{PM}_{10}\right)$ merupakan campuran asap yang kompleks dan heterogen, jelaga, debu, garam, asam dan logam yang mempunyai konsentrasi bervariasi, ukuran, komposisi kimia, luas permukaan dan sumber asalnya. ${ }^{(1)(6)}$ Konsentrasi partikel debu tergantung pada lokasi dan waktu. $^{(7)}$

Berbagai studi menunjukkan bahwa transportasi merupakan sumber utama dari pencemaran udara dimana sebagai penyumbang $70 \%$ dari total pencemaran udara. ${ }^{(8)}$ Penelitian terhadap pekerja proyek konstruksi X di Depok menyatakan bahwa
PM10 menimbulkan gangguan kesehatan Infeksi Saluran Pernafasan Akut (ISPA) secara signifikan pada pekerja proyek konstruksi. (9) Hasil penelitian pada PT Varia Usaha Beton di Sidoarjo tahun 2015 menyatakan bahwa pajanan $\mathrm{PM}_{10}$ mengakibatkan gangguan kesehatan pada mata seperti kemerahan pada mata $(62,5 \%)$, pedih pada mata $(81,25 \%)$ dan gatal pada mata $(75 \%) .{ }^{(10)}$ Pengaruh pajanan $\mathrm{PM}_{10}$ di udara terhadap keluhan sistem pernafasan masyarakat $\mathrm{X}$, dimana setiap peningkatan intake $1 \mathrm{mg} / \mathrm{kg} / \mathrm{hari}$ akan menyebabkan risiko terjadinya keluhan kesehatan sistem pernafasan sebesar 2,778 kali dan responden dengan riwayat penyakit pernafasan akan menyebabkan risiko terjadinya keluhan system pernafasan sebesar 4,394 kali. (11) Penelitian yang dilakukan di PT Intimkara Ternate, konsentrasi PM10 dapat menyebabkan gangguan pernafasan seperti batuk berdahak dan sesak nafas. Pencemar partikulat apabila terhirup dalam jumlah banyak dalam waktu yang lama dapat menyebakan kerusakan fungsi organ pernafasan. ${ }^{(12)}$ Pekerja di Unit Packer PT X bagian pengantongan semen menyatakan bahwa pajanan debu dalam waktu yang lama dapat memberikan pengaruh negatif terhadap kesehatan tenaga kerja. Estimasi resiko menunjukkan tingkat resiko pada pekerja dalam 30 tahun mendatang selama masih bekerja. ${ }^{(13)}$ Risiko kesehatan pajanan $\mathrm{PM}_{10}$ pada pedagang di kawasan Pasar Siteba Kota Padang mulai ada dan beresiko mengalami gangguan saluran pernafasan pada masa 30 tahun mendatang. ${ }^{(14)}$ Risiko pajanan kesehatan $\mathrm{PM}_{10}$ pada pekerja industri di Kebon Nanas telah ada dan perlu dilakukan upaya pengendalian pada durasi pajanan $>5$ tahun. Estimasi risiko mulai muncul pada durasi $>5$ tahun karena beberapa pekerja yang di wawancarai telah bekerja lebih dari 5 tahun. Risiko pajanan $\mathrm{PM}_{10}$ rata-rata yang di terima pedagang kaki lima sudah tidak aman lagi pada masa 15 tahun mendatang dan pada konsentrasi $\mathrm{PM}_{10}$ maksimum sudah tidak aman pada 5 tahun yang akan datang. ${ }^{(8)}$ Hasil penelitian tingkat risiko pajanan life time pada pekerja mebel di Jepara menyatakan bahwa pekerja memiliki risiko non karsinogenik.(15)

Risiko adalah kemungkinan yang mungkin dapat atau tidak terjadi, salah satu cara untuk 
mengetahui besaran risiko dilakukan analisis risiko kesehatan lingkungan (ARKL). ARKL merupakan model matematis yang telah digunakan di sebagian negara maju untuk menentukan besaran risiko akibat pencemaran lingkungan yang memberikan paparan kepada manusia. ${ }^{(16)(17)}$

Kawasan Gunung Sarik Kota Padang merupakan tempat penambangan tanah liat yang digunakan sebagai bahan baku utama untuk pembuatan semen atau timbunan perumahanperumahan. Hasil survey pendahuluan, pengambilan tanah liat dilakukan sejak tahun 1995 oleh lima perusahaan industri. Pengangkutan tanah liat menggunakan truk yang beroperasi dari jam 08.00 18.00 dengan jumlah kendaraan sebanyak 50 unit dengan total 150 rit dengan tonase kendaraan kapasitas 20 ton. Selain kendaraan pengangkut tanah, jalan Gunung Sarik juga dilalui kendaraan roda empat dan roda dua. Emisi Sumber debu berasal dari kendaraan yang mengangkut tanah liat. Tanah tersebut jatuh saat proses pengangkutan ke lokasi tujuan, sehingga jejak tanah yang jatuh menimbulkan debu. Emisi kendaraan ini menghasilkan debu $\mathrm{PM}_{10}$ yang dapat memberikan gangguan kesehatan pada masyarakat. Sepanjang jalan tersebut merupakan kawasan padat pemukiman, terdapat tempat pendidikan Sekolah Dasar/ Madrasah, pertokoan serta pedagang penjual makanan dan minuman. Hasil wawancara dengan beberapa warga masyarakat, sebanyak $80 \%$ merasakan keluhan gangguan saluran pernafasan.

Penelitian ini bertujuan untuk mengetahui tingkat risiko kesehatan lingkungan akibat pajanan $\mathrm{PM}_{10}$ pada kegiatan penambangan tanah liat di Gunung Sarik Kota Padang Tahun 2019.

\section{MATERI DAN METODE}

Penelitian ini menggunakan metode Analisis Risiko Kesehatan Lingkungan (ARKL). ARKL bertujuan untuk menghitung tingkat risiko yang diterima suatu populasi akibat pajanan agen pencemar di lingkungan. Metode ini tidak digunakan untuk menganalisis hubungan pajanan agen risiko dengan gangguan kesehatan. Penelitian dilaksanakan bulan April sampai November 2019, sebanyak 53 responden berlokasi di Gunung Sarik Kota Padang. Populasi adalah warga yang tinggal di kelurahan Gunung Sarik. Pengambilan sampel manusia menggunakan metode sistematis (systematic sampling) sedangkan pengambilan sampel PM10 menggunakan Staplex Model TFIA-2 Series High Volume Air Sampler. Titik sampling debu sebanyak 4 titik dengan 2 kali pengukuran untuk melihat persebaran debu dari sumber pencemar potensial. Data penunjang, data antrophometri dan pola aktifitas dikumpulkan melalui wawancara menggunakan kuesioner untuk mengetahui faktor-faktor pemajanan. Data antropometri dan pola aktifitas yang dikumpulkan berupa berat badan $(\mathrm{Wb})$, lama pajanan per hari $\left(\mathrm{t}_{\mathrm{e}}\right)$ frekuensi pajanan dalam setahun $\left(f_{e}\right)$ dan durasi pajanan $\left(D_{t}\right)$ Hasil pengukuran dianalisis menggunakan metode ARKL.

Metode ARKL bukan merupakan kajian epidemiologi untuk mencari hubungan namun mengidentifikasi bahaya apa saja yang membahayakan, memahami hubungan anatar dosis agen risiko dan respon tubuh, mengukur seberapa besar pajanan agen risiko dan menetapkan tingkat risiko dan efeknya pada populasi. Tahapan analisis risiko dimulai dari identifikasi bahaya dan sumber risiko, analisis dose respon, analisis pajanan, karakterisasi risiko dan manajemen risiko. ${ }^{(16)}$ Karateristik risiko dilakukan untuk menetapkan tingkat risiko, dengan kata lain menentukan apakah agen risiko pada konsentrasi tertentu yang dianalisis pada ARKL berisiko atau tidak beresiko menimbulkan gangguan kesehatan pada masyarakat dengan karakteristik seperti berat badan, laju inhalasi, waktu, frekuensi, durasi pajanan. Karateristik risiko efek non karsinogenik dinyatakan dengan tingkat risiko (Risk Quotient) merupakan pembagian antara asupan inhalasi ( $I$ ) dengan Reference Concentration (RfC) (persamaan 1). Asupan inhalasi merupakan jumlah konsentrasi yang dihirup per kilogram berat badan perharinya (persamaan 2). Suatu keadaan dinyatakan beresiko dan dibutuhkan manajemen pengendalian jika RQ $>1$. Pengelolaan risiko merupakan tindak lanjut yang harus dilakukan bilamana hasil karaterisasi risiko menunjukkan tingkat risiko yang tidak aman.

$$
\begin{aligned}
& R Q=\frac{l}{R / Q} \\
& I=\frac{C R t_{i} f_{1} D_{i}}{W_{b} r_{a w g}}
\end{aligned}
$$

Keterangan :

I : Asupan Inhalasi (mg risk agent $/ \mathrm{kg}$ berat badan individu/ hari)

C : Konsentrasi risk agent di udara $\left(\mathrm{mg} / \mathrm{m}^{3}\right.$ untuk udara, $\mathrm{mg} / \mathrm{L}$ untuk air, $\mathrm{mg} / \mathrm{kg}$ untuk makanan/ pangan

$\mathrm{R}$ : Laju inhalasi $\left(\mathrm{m}^{3} / \mathrm{jam}\right)$, untuk dewasa $20 \mathrm{~m} 3 /$ hari atau $0,83 \mathrm{~m} 3 /$ jam ; anak-anak 12 $\mathrm{m} 3 /$ hari atau $0,5 \mathrm{~m} 3 / \mathrm{jam}$

$t_{e} \quad: \quad$ Lama pajanan (jam/ hari)

$\mathrm{f}_{\mathrm{e}} \quad$ : Frekuensi pajanan, 350 hari/ tahun untuk nilai default residensial

$\mathrm{D}_{\mathrm{t}} \quad$ : Durasi pajanan, 30 tahun untuk default bagi populasi residensial

$\mathrm{W}_{\mathrm{b}}$ : Berat badan individu ( $\mathrm{kg}$ ) dewasa $70 \mathrm{~kg} /$ $55 \mathrm{~kg}$

$t_{\text {avg }}$ : Periode waktu rata-rata (30 tahun $x 365$ hari/ tahun (non karsinogen) atau 70 tahun $\mathrm{x}$ 365 hari/ tahun (karsinogen)

RQ : Risk Quotient

I : Inhalasi

RfC : Reference Concentration (untuk pajanan melalui inhalasi), nilai $R f C$ PM10 sebesar $0,005 \mathrm{mg} / \mathrm{kg} / \mathrm{hari}$.

\section{HASIL DAN PEMBAHASAN}

Hasil pengukuran terhadap Risk agent (RQ) pencemar udara akibat kegiatan penambangan di 
sepanjang jalan Gunung Sarik Kota Padang dengan alat yang digunakan dalam pengambilan sampel $\mathrm{PM}_{10}$ Staplex Model TFIA-2 Series High Volume Air Sampler menunjukkan bahwa hasil pengukuran konsentrasi $\mathrm{PM}_{10}$ tertinggi adalah di titik 4 sebesar $152 \mathrm{ug} / \mathrm{Nm} 3$, konsentrasi PM10 pada titik 1,2, dan 3 masih berada di bawah baku mutu. Titik 4 sudah melewati baku mutu atau Nilai Ambang Batas (NAB) dengan konsentrasi 152 ug/Nm3. Berdasarkan Peraturan Pemerintah Republik Indonesia Nomor 41 tahun 1999 tentang Pengendalian Pencemaran Lingkungan NAB PM10 adalah 150 ug/Nm3 (tabel 1). ${ }^{(18)}$

Survei dilakukan pada 53 orang untuk mendapatkan gambaran umum karateristik antropometri dan pola aktifitas masyarakat di sepanjang jalan Gunung Sarik. Variable yang disurvei adalah berat badan $(\mathrm{Wb})$, lama pajanan per hari $\left(\mathrm{t}_{\mathrm{e}}\right)$ frekuensi pajanan dalam setahun $\left(f_{e}\right)$ dan durasi pajanan $\left(D_{t}\right)$ yang diasumsikan sebagai pola pajanan masyarakat terhadap risiko PM10 dari lingkungan sekitar tempat tinggalnya. Rata-rata umur masyarakat adalah 39 tahun. Umur menjadi salah satu variable penentuan laju inhalasai $(R)$ yang akan berpengaruh terhadap asupan PM10, Hasil Berat badan $\left(\mathrm{W}_{\mathrm{b}}\right)$ rata rata adalah terendah responden $58 \mathrm{~kg}$ dengan berat badan tertinggi adalah $70 \mathrm{~kg}$. Lama pajanan harian tertinggi adalah $17 \mathrm{jam} / \mathrm{hari}$, frekuensi pajanan responden $\left(f_{e}\right) 345$ hari/ tahun. Durasi pajanan $\left(D_{t}\right)$ terendah adalah 15 tahun, durasi pajanan paling lama 30 tahun. Laju inhalasi dengan default orang dewasa adalah $20 \mathrm{~m}^{3} /$ hari atau $0,83 \mathrm{~m}^{3} / \mathrm{jam}^{(13)}$

Tabel 3 menunjukkan bahwa hasil perhitungan nilai RQ pada titik sampling. Nilai RQ pada titik I, II dan III berada di bawah $1(\mathrm{RQ}<1)$ sehingga dapat dikatakan bahwa risiko yang diterima oleh masyarakat masih dapat dikatakan aman. Hal ini disebabkan kosentrasi agen risiko berada dibawah baku mutu. Namun meskipun berada di bawah baku mutu, tidak menyebabkan populasi bebas dari risiko gangguan kesehatan. Sementara nilai RQ pada titik sampling IV mempunyai nilai $\mathrm{RQ}>1$ artinya pemajanan tidak aman bagi masyarakat lingkungan sekitarnya. Pajanan $\mathrm{PM}_{10}$ yang terhirup oleh masyarakat disekitar kawasan titik IV dengan berat badan $60 \mathrm{~kg}$, waktu pajanan 17 jam/hari selama 339 hari/tahun tidak aman atau beresiko terhadap efek non karsinogenik dalam masa 22 tahun mendatang selama berada atau tinggal di kawasan titik IV, sedangkan titik I, II dan III mempunyai nilai $\mathrm{RQ}<1$.

Faktor individu merupakan variabel penting yang dapat mempengaruhi besarnya suatu agen risiko di terima individu adalah karateristik responden dan pola pajanan. Semakin berat badan maka semakin kecil dosis internal yang diterima. Usia mempengaruhi daya tahan tubuh terhadap pajanan toksik atau bahan kimia. Semakin tinggi usia maka daya tahan tubuh akan semakin berkurang. Semakin sering dan lama individu berada pada lingkungan yang tercemar atau berpolusi maka akan semakin besar jumlah agen risiko yang masuk ke dalam tubuh dan risiko untuk terjadi efek gangguan kesehatan semakin besar. ${ }^{(13)}$

Pengelolaan risiko dilakukan dengan menentukan batas aman dari faktor pajanan yan ingin dicapai dan melakukan upaya pengelolaan melalui banyak pendekatan, yaitu pendekatan teknologi, sosial ekonomi, maupun institusional. Menghitung dan menentukan batas aman, RfC adalah konsentrasi referensi dari agen risiko. ${ }^{(5)}$

Tabel 1. Hasil Pengukuran Konsentrasi $\mathrm{PM}_{10}$

\begin{tabular}{cccc}
\hline Lokasi & $\begin{array}{c}\text { Lama } \\
\text { Pengukuran }\end{array}$ & Konsentrasi & Baku Mutu \\
\hline Titik 1 & 6 jam & $48 \mathrm{ug} / \mathrm{Nm} 3$ & $150 \mathrm{ug} / \mathrm{Nm} 3$ \\
Titik 2 & 6 jam & $46 \mathrm{ug} / \mathrm{Nm} 3$ & $150 \mathrm{ug} / \mathrm{Nm} 3$ \\
Titik 3 & 6 jam & $29 \mathrm{ug} / \mathrm{Nm} 3$ & $150 \mathrm{ug} / \mathrm{Nm} 3$ \\
Titik 4 & 6 jam & $152 \mathrm{ug} / \mathrm{Nm} 3$ & $150 \mathrm{ug} / \mathrm{Nm} 3$ \\
\hline
\end{tabular}

Tabel 2. Karateristik Antrophometri dan Pola Aktivitas Responden

\begin{tabular}{lccccc}
\hline \multicolumn{1}{c}{ Karateristik } & Titik I & Titik II & Titik III & Titik IV & Rata-rata \\
\hline Berat Badan (Wb( (kg) & 58 & 70 & 69 & 60 & 64 \\
Durasi Pajanan (te) (jam/hari) & 14 & 10 & 15 & 17 & 14 \\
Frekuensi Pajanan $\mathrm{f}_{\mathrm{e}}($ hari/th) & 342 & 320 & 345 & 339 & 337 \\
Durasi Pajanan (Dt) (tahun) & 15 & 27 & 30 & 22 & 24 \\
\hline
\end{tabular}

Sumber : Data Primer, 2019

Tabel 3. Hasil Perhitungan Nilai Risk Quotient (RQ) PM $_{10}$

\begin{tabular}{|c|c|c|c|c|}
\hline Titik & I & RfC & RQ & Risiko \\
\hline I & 0,0045 & 0,005 & 0,90 & Tidak Beresiko \\
II & 0,0043 & 0,005 & 0,86 & Tidak Beresiko \\
III & 0,0049 & 0,005 & 0,99 & Tidak Beresiko \\
IV & 0,0243 & 0,005 & 4,87 & Beresiko \\
\hline
\end{tabular}

Keberadaan kegiatan penambangan tanah liat di Gunung Sarik Kota Padang dinilai banyak kekurangannya akan ramah lingkungan. Masyarakat merasa resah terutama terhadap polusi seperti debu tanah penambangan yang mencemari lingkungan.
Hasil pengukuran Konsentrasi $\mathrm{PM}_{10}$ di titik IV tertinggi dibandingkan titik lokasi sampling lainnya, yaitu sebesar $152 \mathrm{ug} / \mathrm{Nm} 3$ sudah melewati baku mutu atau nilai ambang batas yang telah ditetapkan dalam Peraturan Pemerintah Republik Indonesia Nomor 41 
tahun 1999 tentang pengendalian Pencemaran Lingkungan dengan nilai konsentrasi $\mathrm{PM}_{10}$ (150 $\mathrm{ug} / \mathrm{Nm}^{3}$ ). Jumlah kendaraan dan jarak dari sumber pencemar menjadi penyebab tingginya kadar debu pada titik lokasi sampling IV dibandingkan titik sampling lainnya. Kondisi ini memungkinkan terjadi karena sumber $\mathrm{PM}_{10}$ dapat berasal dari aktivitas transportasi atau emisi kendaraan. Pembakaraan bahan bakar fosil dari aktivitas transportasi merupakan penyumbang terbesar emisi partikulat ke udara. Partikulat juga berasal dari debu jalan terutama jalan yang tidak beraspal. ${ }^{(19)}$

Hal ini mengindikasikan bahwa tingginya kadar debu pada udara ambien dipengaruhi oleh kepadatan kendaraan, dekatnya lokasi dengan jalan. Semakin jauh jarak rumah dengan sumber pencemar maka paparan konsentrasi debu yang diterima semakin kecil. ${ }^{(20)}$

Penelitian yang dilakukan Suhananto pengukuran $\mathrm{PM}_{10}$ di sepanjang Jalan Raya Bogor Kota Depok terdapat satu titik lokasi pengukuran yang melewati baku mutu setelah dibandingkan dengan Peraturan Pemerintah Republik Indonesia Nomor 41 Tahun 1999 tentang Pengendalian Pencemaran Lingkungan dengan konsentrai $\mathrm{PM}_{10}$ sebesar 159 $\mathrm{ug} / \mathrm{Nm}^{3}$. Tingginya konsentrasi pada titik tersebut disebabkan adanya industri disekitar titik pengukuran dan juga merupakan titik kemacetan. Perbedaaan konsentrasi $\mathrm{PM}_{10}$ di wilayah tidak bervegetasi ratarata konsentrasinya tinggi dibandingkan dengan wilayah bervegetasi. ${ }^{(21)}$

Kendaraan yang melintasi sepanjang jalan Gunung Sarik di antaranya kendaraan roda dua, angkutan umum, truk pembawa tanah liat dan mobil pribadi. Jumlah kendaraan yang melintas dan kegiatan truk pengangkut tanah liat dapat menjadi penyebab tingginya kadar partikel debu pada lokasi titik sampling.

Pembakaran bahan bakar domestik dari permukaan tanah dapat berkontribusi meningkatnya pencemaran partikulat ke udara. $^{(6)}$ Selain itu kelembaban juga berpengaruh signifikan pada konsentrasi partikel debu. Kelembaban yang meningkat akan memberikan dampak peningkatan pada konsentrasi partikel debu. Kecepatan angin dan suhu menyimpulkan suhu yang tinggi di udara dan angin yang berhembus lebih cepat akan menyebabkan penyebaran partikel debu di udara semakin tinggi. ${ }^{(7)(20)}$ Risiko akan lebih besar pada lokasi yang tertimpa arah angin lebih besar. (19) Sepanjang jalan Gunung Sarik tidak terdapat pohon-pohon yang dapat menyerap polusi. Keberadaan pohon-pohon dan tanaman berpengaruh terhadap rendah atau tingginya konsentrasi PM10 pada udara ambien. ${ }^{(14)}$

Masyarakat di sepanjang jalan yang terindikasi beresiko kesehatan terhadap pajanan $\mathrm{PM}_{10}$ perlu dilakukan manajemen risiko untuk mengurangi dampak pajanan terhadap masyarakat pada durasi pajanan yang lama. Seluruh faktor pemajanan menggunakan nilai yang di dapat dari hasil survey pada masyarakat. Berdasarkan wawancara mengenai gambaran gangguan pernafasan, gejala gangguan pernafasan yang dominan dialami responden selama tinggal di sepanjang jalan tersebut adalah sesak nafas, nyeri dada, dan batuk sebanyak $86 \%$ yang merupakan gejala potensial apabila terpapar $\mathrm{PM}_{10}$ dalam jangka waktu yang cukup lama. Faktor karateristik tempat tinggal mempunyai pengaruh terhadap gangguan saluran pernafasan adalah jarak tempat tinggal yang dekat dengan sumber pencemar, ventilasi yang tidak memenuhi syarat dan rumah semi permanen.

Analisis pajanan dilakukan berdasarkan asupan atau intake pajanan. Semakin besar nilai konsentrasi $\mathrm{PM}_{10}$ maka semakin besar asupan (intake) yang diterima oleh responden. Variable intake merupakan hasil perkalian konsentrasi (C) $\mathrm{PM}_{10}$ dan memasukkan nilai-nilai karateristik antropometri dan pola aktifitas yang terdiri dari laju asupan $(\mathrm{R})$, waktu pajanan $\left(\mathrm{t}_{\mathrm{e}}\right)$, frekuensi pajanan $\left(\mathrm{f}_{\mathrm{e}}\right)$, durasi pajanan $\left(\mathrm{D}_{\mathrm{t}}\right)$

,berat badan $\left(\mathrm{W}_{\mathrm{b}}\right)$ dan periode rata-rata $\left(\mathrm{t}_{\mathrm{avg}}\right)$. perbedaan nilai intake pada masing-masing titik lokasi sampling dipengaruhi oleh perbedaan konsentrasi $\mathrm{PM}_{10}$. Nilai asupan atau intake yang lebih tinggi menjadikan daerah tersebut lebih beresiko dari pada daerah lainya. Semakin lama durasi pajanan harian, frekuensi pajanan tahunan, dan waktu responden yang terpajan agen risiko maka akan semakin besar nilai asupan (intake) yang diterima oleh orang tersebut dan semaik beresiko terhadap gangguan kesehatan akibat pajanan agent tersebut. Selain itu nilai supan atau intake berbading terbalik dengan berat badan, maka semakin besar berat badan seseorang, akan semakin kecil asupan (intake) yang diterima oleh responden.

Konsentrasi pajanan $\mathrm{PM}_{10}$ pada transportasi dapat dilakukan dengan membatasi usia kendaraan bermotor dan penggunaan bahan bakar gas. Penelitian Laumbach menyimpulkan pengontrolan pada emisi kendaraan dapat menjadi strategi untuk menurunkan cemaran $\mathrm{PM}_{10}{ }^{(22)}$ Selain itu menanam pohon atau memanfaatkan vegetasi di sepanjang jalan Gunung Sarik. Pengelolaan risiko paparan debu pada masyarakat dilakukan dengan menurunkan konsentrasi pada sumber pencemar dan menanam pohon di area pemukiman sebagai vegetasi. ${ }^{(23)}$

Partisipasi masyarakat perlu ditingkatkan dengan mensosialisasikan tanaman penyerap polutan, memasang barrier/ kain kasa untuk menangkal partikulat masuk ke dalam rumah dan melakukan penyiraman jalan secara rutin guna mengurangi tumpahan tanah yang jatuh saat proses pengangkutan. Selain itu tanah yang di angkut di tutupi dengan terpal agar tanah tidak terjatuh selama proses perjalanan. Pengendalian terhadap waktu pajanan dan frekuensi pajanan terhadap masyarakat yang tinggal di sepanjang jalan tersebut dapat dilakukan dengan menggunakan masker sebagai Alat Pelindung Diri (APD). Melihat risiko yang ditimbulkan oleh aktifitas kendaraan bermotor dan kendaraan pengangkut tanah liat perlu dilakukan tindak lanjut dari penelitian ini. Pihak yang bertanggung jawab agar dapat mengurangi dampak 
dari pajanan PM ${ }_{10}$. Perlu dibuat suatu regulasi atau pengaturan lalu lintas kendaraan pengangkut tanah liat.

\section{SIMPULAN}

Hasil penelitian menunjukkan bahwa terdapat satu titik pengukuran dengan konsentrasi $\mathrm{PM}_{10}$ udara ambien di Gunung Sarik 0,152 $\mu \mathrm{g} / \mathrm{m} 3$ melewati baku mutu sesuai PP No 41 Tahun 2009 yaitu $150 \mu \mathrm{g} / \mathrm{m}^{3}$ Hasil analisis risiko $R Q>1$, artinya pemajanan tidak aman bagi masyarakat yang tinggal di sepanjang Jalan Gunung Sarik dan sebanyak 43 responden $(86 \%)$ memiliki gejala gangguan saluran pernafasan.

\section{DAFTAR PUSTAKA}

1. De Donno A, De Giorgi M, Bagordo F, Grassi T, Idolo A, Serio F, et al. Health risk associated with exposure to PM10 and benzene in three Italian towns. Int J Environ Res Public Health. 2018;15(8):1-

13.https://doi.org/10.3390/ijerph15081672

2. Kelly FJ, Fussell JC. Air pollution and public health: emerging hazards and improved understanding of risk. Environ Geochem Health. 2015;37(4):631-

49.https://doi.org/10.1007/s10653-015-9720-1

3. Khairina M. The Description of CO Levels, $\mathrm{COHb}$ Levels, And Blood Pressure of Basement Workers X Shopping Centre, Malang. J Kesehat Lingkung.

2019;11(2):150.https://doi.org/10.20473/jkl.v11i 2.2019.150-157

4. WHO. Air pollution levels rising in many of the world's poorest cities. http://www.who.int/mediacentre/news/releases/2 016/air-pollution-rising/en/ [Internet]. Air pollution levels rising in many of the world's poorest cities. 2016. p. 8-10. Available from: https://www.who.int/news-room/headlines/1205-2016-air-pollution-levels-rising-in-many-ofthe-world-s-poorest-cities

5. Bedah S, Latifah I. Risiko pajanan konsentrasi pm 10 dan pm 2,5 di kecamatan ciwandan, cilegon jawa barat tahun 2014. J Ilm Kesehat. 2017;9(1):93-102.

6. Lina Thabethe ND, Engelbrecht JC, Wright CY, Oosthuizen MA. Human health risks posed by exposure to PM10 for four life stages in a low socio-economic community in South Africa. Pan Afr Med J. 2014;18:112.https://doi.org/10.11604/pamj.2014.18.206.33 93

7. Aisyiah K, Sutikno, Latra IN. Pemodelan Konsentrasi Partikel Debu (PM10) pada Pencemaran di Kota Surabaya dengan Metode Geographically-Temporally Weighted Regression. J Sains dan Seni POMITS. 2014;2(1):1-6.

8. Wulandari A, Darundiati Y, Raharjo M. Analisis Risiko Kesehatan Lingkungan Pajanan Particulate Matter (Pm10) Pada Pedagang Kaki
Lima Akibat Aktivitas Transportasi (Studi Kasus: Jalan Kaligawe Kota Semarang). J Kesehat Masy Univ Diponegoro. 2016;4(3):67791.

9. Putri A, Dwi F, Achmadi UF. AKUT ) PADA PEKERJA PROYEK KONSTRUKSI $X$ DI DEPOK Abstrak. 2020;1(3):272-83.

10. Pitaloka APR. Paparan PM10 dan Keluhan Kesehatan Mata Pekerja Bagian Produksi PT Varia Usaha Beton, Sidoarjo. J Ilm Keperawatan. 2016;2(2).

11. Firmanto J, Firdaust $M$, Hikmandari $H$. Pengaruh Pajanan Particulate Matter 10 (Pm10) Di Udara Terhadap Keluhan Sistem Pernapasan Masyarakat Di Sekitar Pabrik Semen X Desa Tipar Kidul Kecamatan Ajibarang Tahun 2018. Bul Keslingmas. 2019;38(2):23442.https://doi.org/10.31983/keslingmas.v38i2.48 82

12. Monalisa MS. Pengaruh Konsentrasi PM 10 Dengan Beberapa Keluhan Kesehatan Di PT Intimkara Ternate. Univ Muhammadiyah Palu MPPKI. 2020;3(1):1-6.

13. Siswati, Diyanah KC. Analisis Risiko Pajanan Debu (Total Suspended Particulate) di Unit Packer PT. X. J Kesehat Lingkung. 2017;9(1):100-

10.https://doi.org/10.20473/jkl.v9i1.2017.100101

14. Gusti A, Arlesia A, Anshari LH. Penurunan Derajat Kesehatan Pedagang Akibat Pajanan Debu PM 10 Decreasing the Degrees of Health Due to PM 10 Exposure on Traders. J MKMI. 2018;14(3):23340.https://doi.org/10.30597/mkmi.v14i3.4260

15. Dian Indriyani. Analisis Risiko Kesehatan Lingkungan Pajanan Debu Kayu Pada Pekerja Di Industri Mebel Cv. Citra Jepara Kabupaten Semarang. J Kesehat Masy. 2017;5(5):571-80.

16. Direktur Jendral PP dan PL Kementerian Kesehatan. Pedoman Analisis Risiko Kesehatan Lingkungan (ARKL). 2012.

17. Syahrul Basri; Emmi Bujawati; Munawir Amansyah; Habibi; Samsiana. Analisis risiko kesehatan lingkungan. J Kesehat. 2014; VII(2):427-42.

18. Peraturan Pemerintah. Peraturan Pemerintah no. 41 tentang Pengendalian Pencemaran udara. Peratur Pemerintah no 41 tentang Pengendali Pencemaran Udar [Internet]. 1999;(1):1-5.

19. Azni IN, Wispriyono B, Sari M. Analisis Risiko Kesehatan Pajanan Pm 10 Pada Pekerja Industri Readymix Pt. X Plant Kebon Nanas Jakarta Timur. J MKMI [Internet]. 2015;10:203-9.

20. Ma'rufi I. Analisis Risiko Kesehatan Lingkungan (SO2 , H2S, NO2 dan TSP) Akibat Transportasi Kendaraan Bermotor di Kota Surabaya. Media Pharm Indones. 2018;1(4):189.https://doi.org/10.24123/mpi.v1i4 .770 
21. Suhananto Z. Perbandingan Tingkat Risiko Pajanan PM10 pada Jalan Raya Bervegetasi dan Tidak Bervegetasi terhadap Kesehatan Penduduk. 2013;1-15.

22. Laumbach R, Meng Q, Kipen H. What can individuals do to reduce personal health risks from air pollution? J Thorac Dis. 2015;7(1):96107.

23. Khaniabadi YO, Polosa R, Chuturkova RZ, Daryanoosh M, Goudarzi G, Borgini A, et al. Human health risk assessment due to ambient PM10 and SO2 by an air quality modeling technique. Process Saf Environ Prot [Internet]. 2017;111:346-

54.https://doi.org/10.1016/j.psep.2017.07.018 